UDC $81-119$

MARTYCH RUSLANA,

Borys Grinchenko Kyiv University (Kyiv, Ukraine)

e-mail:r.martych@kubg.edu.ua,DOI0000-0002-7755-4496

\title{
EVOLUTION OF PERCEPTION OF "LIVING" IN RELIGIOUS AND PHILOSOPHICAL DISCOURSE
}

\begin{abstract}
Modern scientific discourse, basing on the postnonclassical scientific world picture and on the permanent-transitive fluctuations of the postmodern period, still includes such eternal questions as the problem of a man, human life and health, the fundamental factors of the world and human being in the world. Life is the only biologically possible way of human being in the world. Its value lies not only in the specificities of existing biological forms and various manifestations, which are nevertheless a unique phenomenon of being in their totality, but also in the possibility of selfreflection, conscious experience of the phenomenon itself and the ability to form symbolic pictures of the existential world on this basis. The purpose of the article is to examine the transformation of scientific discourse on the concept of "living" within the framework of the formation and development of religious and ethical studies. To achieve this purpose, the author analyzes the categorical framework of the concept of "living". Analyzing classical philosophical and modern scientific approaches to the definition of the concept of "living", the author distinguishes two main approaches to the definition of life: substrate and functional. In the article the main attention is focused on the analysis of religious and bioethical discourses in the study of "living". Bioethical discourse proceeds from the need for identifying moral norms and imperatives that can answer the question of the limits of the existence of "living" and determine the moral possibilities of impact (expansion or narrowing) on these limits. One of the fundamental problems of bioethics is the problem of life as a value. In modern bioethical discourse there are two main points of view in this regard. The first may be named the ethics of the sacrality of life or life as the highest value (sanctity of life), the second - the ethics of the quality life (quality of life). The sacrality of life implies an attitude to the phenomenon of "living" as to the object of exceptional weight, of the most important value, and on this basis requires a reverent attitude to it. This approach has the most clear and full representation by modern religious discourse. The religious content of the bioethical discourse on "living" is manifested, firstly, in approval of the objective ontological status of the human personality by the Christian personalism; secondly, in the teachings of Christian theologians who claim the beauty and righteousness of life created by God, where nature and human are understood as something sacral, and therefore the actions against them are sinful and unacceptable; thirdly, the basis of human life is rooted in the spiritual world of human himself related to the divine transcendence. In is concluded that modern religious and ethical discourse forms a system of categories and concepts that describe applied ethical conceptual constructs in order to form a person's moral attitude to all living. The proposed author's approach allowed establishing the essence of modern bioethical discourse in the study of "living".
\end{abstract}

Key words: existence; human; life; living; concept; discourse; religion; ethics; bioethics; value.

\section{Introduction}

In the age of major social transformations, when the change of value paradigms takes place, humanity inevitably needs to find new responses to the global historical challenges it faces. Modern scientific discourse, basing on the postnonclassical scientific world picture and on the permanent-transitive fluctuations of the postmodern period, still includes such eternal questions as the problem of a man, human life and health, the fundamental factors of the world and human being in the world.

Life is the only biologically possible way of human being in the world. Its value lies not only in the specificities of existing biological forms and various manifestations, which are nevertheless a unique phenomenon of being in their totality, but also in the possibility of self-reflection, conscious experience of the phenomenon itself and the ability to form symbolic pictures of the existential world on this basis. The philosophical reflection of "life", in the opinion of H. Rickert, should proceed from the fact that "Life should be placed in the center of the world whole, and everything philosophy has to interpret must be relative to life. It appears as the key to all the doors of a philosophical building. Life is declared the own "essence" of the world and at the same time an organ of its cognition. Life itself should philosophize from itself without the help of other concepts, and such a philosophy should be directly experienced (Rikkert, 1998: 275).

The analysis of the concept of "living" in scientific discourse

Let us turn to the categorical apparatus which allows 
forming the framework of the studied problems. By definition of S. Averintsev, life is "a form of existence of matter naturally emerging under certain conditions in the process of its development, living objects differ from nonliving by metabolism (an essential condition of life), irritability, ability to breed, grow, actively regulate its structure and functions, capacity for various forms of movement, adaptability to the environment, etc. The specifics of living objects and life processes may be characterized in terms of both their material structure and the most important functions that underlie all manifestations of life" (Averintsev, 1989: 192).

The reconstruction of the process of understanding the phenomenon of the "living" as the most probable "beginning" is provided by the philosophical treatises of

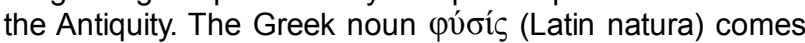
from the verb $\varphi v ́ \omega$, which means "cultivate", "give birth", "produce to the world" or "raise", "give life", "emerge". And from here comes the close proximity, almost synonymy of

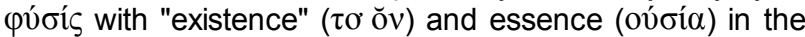
philosophical language. In the latter meaning the verb púo is close to rívoual which in turn is linked with the Latin natus - natura, which had become the basis for the verb "to be" in the Jewish language. The ancient Greek interpretation of this word is defined like what carries the meaning of existence not as a resultative stay, but as "origin to the world", which in the Latin sense represents "emergence", "birth". Plato refuses the understanding of nature as something which is arbitrarily acting, where things, animals, plants and the like emerge due to an unreasonable cause. Their appearance is associated with the "wisdom of divine art" (Plato, 1971: 514). Plato believed that all things received their being from the Demiurge and from something unchanging, which is the source for the formation of the idea of creation in early Christianity. On the other hand, nature cannot be understood as "the blind game of the elements", it would be correct to call nature the soul which "rules over all kinds of changes of bodies" as a driving principle (Plato, 1999: 349-350).

In Aristotle's philosophy, nature is defined as living, connected with a certain moment of being. Being is interpreted as a beginning. And to be the beginning means to be the cause of something else, which begins, arises, becomes. Human is a living being, endowed with the spirit, intelligence and capacity for social life. Therefore, the task of a human is "to overcome passion, desires, vices, and by means of charity, asceticism, theurgy, music, poetry, creativity try to achieve fusion with the All" (Aristotle, 2000: 17-71). Entelechy - the moment of eternity, which permeates the body with life, - was defined by Aristotle as the criterion of distinguishing the living from the nonliving. Later, as opposed to the mechanistic interpretation of life processes, the term "vis vitalis" was introduced to designate a special life force. For neoplatonism, which had connected Eastern teachings with Greek philosophy, nature is the last and lowest level of supersensitive reality. For example, Plotinus calls nature "the order that is established by the world soul" as a result of its observing divine ideas. On the other hand, the nature, which operates in inanimate bodies, plants and animals, is the unconscious principle of their bodily life. Sometimes Plotinus identifies nature with the world soul, namely with that part of it, which has departed from the contemplative state and has received a division in bodies. In Plotinus' philosophy, the concept of "nature" is already applied to everything which exists independently. $\mathrm{He}$ calls the cosmos, the soul, the mind, and the All itself "natures" (Plotinus, 1995: 348-352). The neoplatonic tradition continued through the early Middle Ages, when being was considered from the point of view of God as religious truth: the world and nature are dependent, they are created from nothing and disappear without being cared of. In the theological approach, the nuance of meaning in the understanding of the living changes slightly. So, in the "Complete Church Slavonic Dictionary" contains more than thirty terms which are close to the concept of the living. In particular, the most widely used in theological literature concepts are: "живительный" contributes to the preservation of common human forces; "живити" means to protect, keep alive; "живитися" means to receive strength to continue life; "живоначалие" is the reason, or the beginning, of life; "живоносный" is one who bears life in oneself; "живоросленный" is one that contains a vegetable power; "животворецъ" is one who gives life; "животворение" means revival, resurrection; "животно" is the animal world; "животный" is one who has such life in oneself (Dyachenko, 1993: 183-184). Thus, in religious practice the concept of the living includes all spheres of its spreading and organization. But the existence of the living in the world around is dominant. In general, the religious understanding of the living includes both spiritual and subordinate organic unity of the origin. The Christian understanding of the living is already laid in the semantic content of some lexemes of the Jewish language. Two Jewish words, hay and nepeš, convey the concept of "life" in the Old Testament. The first means active existence in which the idea of movement prevails, the second is translated as "soul", "breath" or "life" itself. "Nepeš" is inherent to all living, but it expresses the separate existence of a human and means that man draws life from the divine. But human is an integral being which lives in the unity of soul and body. In the New Testament, three words convey the concept of "life": bios (earthly existence), zōē (life activity inherent to man, the totality of all the elements that constitute life), psychē (animate principle, translated as "soul", in certain moments means earthly life) (Mc Donald, 2003: 460-461). The emergence of life in Christianity is associated with the creation of "creature". "Creature" is understood as "a work, a creature, a being, nature" etc. Sometimes only human is understood under this name in the Holy Scripture. In Christianity, the Biblical perception of human as the "image and likeness of God" internally divided because of the Fall is combined with the doctrine of the divinity of human nature in the person of Christ as a special psychophysical individuality.

With the development of nature science knowledge, worldview changes in the understanding of the living as a part and being as a whole occurred. The works of C. Darwin, I. Schmalhausen, A. Oparin, V. Grant are the basic in the natural science approach to the problem of the origin of life and its evolution, in particular, the origin of human. Two principled approaches, creational and evolutionary, are the lead in modern concepts of existence of living. The first approach postulates the emergence, the formation and development of life as a process that has transcendent authorship, the second explains this process by the evolutionary features of the material world in our planet.

Since life is an object of study of many natural sciences, the question of its essential definition remains the subject of discussion of various natural areas. Since the second half of the twentieth century. Two main approaches to the definition of life, substrate and functional, can be seen clearly since the second half of 20th century. Proponents of the first approach (V. Zhdanov, A. Pasynskyi, A. Mamzin) pay attention to the substrate (protein or DNA molecules) which becomes the carrier of the basic features of the 
living in the interpretation of the essence of life. The adepts of the second approach (A. Oparin, V. Makhovka, P. Makarov, D. Troshin, K. Willi, G. Wells, P. Wells) consider life from the point of view of its basic features (metabolism, selfreproduction, etc.).

The purpose of the article is to examine the transformation of scientific discourse on the concept of "living" within the framework of the formation and development of religious and ethical studies.

\section{Methods}

The purpose of the research predetermined the use of appropriate methodological approaches, in particular: structural-functional (the study of "living" as a complex phenomenon, which is disclosed through identifying the essence of its individual components), semantic (where "living" is considered as a language construct, its lexical and language origin is studied), comparative (comparison of various discourses in the study of "living"), comparativehistorical (study of the change of philosophical-value systems of "living" depending on the change of historical epochs). In addition, general scientific methods of analysis and synthesis, induction and deduction, analogy, generalization were used in the article, which allowed more accurate and deep realization of the purpose of the research.

\section{Results and discussion}

\section{Bioethical discourse on "living"}

It should be noted that today bioethics is one of the most important areas of implementation of the axiological paradigm of the doctrines of life and "living" as a form of its manifestation. It is a branch of scientific knowledge which studies and analyzes the morality of human actions, primarily in the field of medical and biological activities, that emerged in the last quarter of the 20th century as a sphere of cognition. The task of bioethics is to answer questions about the limits of the existence of the "living" and to determine the moral possibilities of impact (expansion or narrowing) on these boundaries through the prism of moral norms and imperatives (Horban, Martych, 2017: 101).

The main directions of modern scientific research, which change the paradigm of views on the essence of the concept of "living", where bioethics is of prime importance, are, in particular, are genetic engineering, gene therapy and cloning. Genetic engineering is a complex of techniques aimed at transferring certain types of genetic information, which was not previously there, to a cell structure of a living being. Actually, artificial creation of the desired mutations and recombinations of the living takes place. The moral problem is the greater if such an intervention is planned with the purpose of experimentation.

Gene therapy in fact is a complex of procedures aimed at deciphering the human genome in order to prevent or treat pathological conditions of a living organism. The obvious ambivalence of such genetic studies should be noted since these studies are aimed at changing the biological essence of the living, and therefore carry significant risks in the case of unsuccessful experimentation or conscious manipulation of the results of experiments.

Cloning of organisms is one of the consequences of genetic engineering. Cloning is the method by which a set of subjects produced from one organism and genetically identical with it can be obtained. With a view to the future, cloning provides for the creation of ideal individuals with unsurpassed capabilities; production of healthy individuals without the risk of hereditary diseases; the creation of a large number of genetically identical subjects for research, etc. However, the issues of human cloning are found to be violating fundamental human rights. Cloning contradicts the principle of equality of human beings, because it allows racial and eugenic selection, violates human dignity.

One of the fundamental problems of bioethics is the problem of life as a value. In modern bioethical discourse there are two main points of view in this regard. The first may be named the ethics of the sacrality of life or life as the highest value (sanctity of life), the second - the ethics of the quality life (quality of life).

The sacredness of life implies an attitude to the phenomenon of "living" as to the object of exceptional weight, of the most important value, and on this basis requires a reverent attitude to it. This approach has the most clear and full representation by modern religious discourse.

Religious content of bioethical discourse on "living"

An essential part of contemporary bioethical discourse is occupied by the discourse of modern Christian theology which has its specificities of manifestations in various streams of Christianity (Horban, Martych, 2018: 103). They manifests themselves, firstly, in approval of the objective ontological status of the human personality by the Christian personalism; secondly, in the teachings of Christian theologians who claim the beauty and righteousness of life created by God, where nature and human are understood as something sacral, and therefore the actions against them are sinful and unacceptable; thirdly, the basis of human life is rooted in the spiritual world of human himself related to the divine transcendence. As researcher I. Siluyanova notes, "modern European traditional bioethics is represented by the discourse of "Christian bioethics" of Catholicism and Protestantism" (Siluyanova, 2001: 21).

Among the bioethical problems, the most controversial in religious discourse is the problem of making human life easier, such as relieving physical suffering during illness. The belief itself determines whether to perceive or not all the benefits of civilization, which provide, if necessary, more comfortable vital activity. Considering only Christianity in our case, we can state the updated approaches to bioethical problems, especially radically it is stated in Protestantism. Protestantism, focused on the autonomy of the personality, moral autonomy, raises these postulates to the fundamental principles of respect for the patient autonomy. In this case, the ethics of life is reduced to the ethics of responsibility (Collange, 1992: 41). Protestant theologians interpret this ethics, rooted in the philosophy of I. Kant, as a fundamental moral principle that a person should be considered as a purpose, and should be treated as a purpose, and not as a means to achieve some other purpose, even the noble one.

The Christian discussion on euthanasia is marked by a special bioethical discursive status, since this problem enclose with the question of human self-identification. According to the Christian canon, human is created by God with "free will", but freedom has boundaries, and religious freedom provides for life in harmony with the nature given to us by God, and not in "rebellion against it". Therefore, in the opinion of Protestant theologians, the concept of complete autonomy of human is a myth. One of the famous Protestant theologians, John Stott, in his argument relies on the Christian doctrines of God and his supreme power, as well as about a human and the in- 
violability of human life. The theologian treats the commandment "Thou shalt not kill" as one that allows taking a person's life only under certain circumstances, which, according to him, include the death penalty and holy war (Stott, 2004: 480). Life itself is a gift from God, and no one except God can give it or take it away: "There is no God but Me. I kill and revive. I mortify and bring back to life, I strike and I heal, and no one will spare from My hand" (BT, 32:39). Life is perceived as a gift to a human, it protects and guards him, therefore a human is obliged to take care of it, to support it, to heal if it is necessary. According to this logic, the interruption of life is unacceptable from the point of view of Protestant Christians. Having decided to take responsibility on the question of voluntary interruption of life, human expresses not the "autonomy of the individual" given to him, but "arrogance before God". The position of Protestantism in this question is that a person makes the choice of euthanasia because of the fear of pain and dependence on others. Therefore, the full support of the patient, including moral support, as well as various pain relievers, which modern medicine has in many, are offered as a solution of this collision.

Questions of life and death are actualized in Christian bioethical discourse not only as the subject's conscious consent to end life, but also in cases of artificial termination of pregnancy, where the subject of the murder is child, even if it is still in the embryonic phase of development. Christian bioethical discourse is characterized with the understanding of a human embryo as a set of characteristics that determine its status from the standpoint of existence (ontological status), duty and responsibility (ethical status) together with the law (legal status)" (Boyko, 2011: 218). Despite the fact that euthanasia is associated with the end of life, and abortion with its beginning, they raise a single ethical problem - the interruption of life and its values.

As opposed to some scientific interpretations that "the embryo is not a human being", the Catholic Vatican issued the Instruction "Donum Vitae", where it allows artificial intervention only in the form of a prenatal diagnostics which has therapeutic nature and is carried out for the sake of the embryo. The Instruction states clearly that any intervention that is not therapeutic in nature, and is conditional on regulation (dominance) over the process of procreation, is unacceptable for Catholicism. Any intervention gives a person the temptation to "go beyond the reasonable domination over nature" (Donum Vitae). The Catholic Church declares non-intervention in the field of experimental sciences on the basis of particular competence, however, taking into account the data of research and technology data, it aims to put forward, by virtue of its evangelical mission and apostolic duty, moral doctrine appropriate the dignity of human and the integral calling of human. Catholic bioethical discourse generally admits that science and technology can help a person as a resource, but they alone cannot be the sense of existence and human progress. Medical care has always been an integral part of Christian culture (according to legend, the apostle Luke was a doctor). However, medical activity, like any other scientific and technical activity, requires unconditional adherence of the criteria of the moral law: it should serve the human individual, human inalienable rights, true and holistic good by the idea and will of the Creator. The Protestant theologians, in turn, interpret this thesis as the fundamental principle that a person should be regarded as a purpose, and not as a means to achieve another, even the noble purpose.
The shift of emphasis in the problem of comprehending the "living" from ontological and epistemological to axiological and ethical should be accepted the peculiarity of modern Orthodox bioethical discourse (Horban, Martych, 2017b: 55-59).

Bioethical discourse is present in the views of Orthodox theologians on the problems of the "living" in the context of acceptance of its human essence. Thus, the Orthodox Church recognizes the human dignity of the embryo at any stage of its development, starting from the early stage. "We do not have a subtle distinction between the embryo formed or not yet formed", says Basil the Great in his first Canonical Epistle included in the Book of Rules of the Orthodox Church (Saint Basil the Great, 2008: 240). On this basis, the Orthodox Church considers deliberate abortion at any stage of pregnancy as murder, as a criminal assault on the sacred gift of human life. Orthodox bioethical discourse also interprets the attitude to any experiments involving the destruction of human embryos in the same way (Melety, 1992).

Regarding the traditional attempts of doctors to do everything possible to support the life of the sick organism and thus prevent its death, modern Orthodoxy proceeds from the relevance of such actions. Surgical treatment, medical use of narcotics and even artificial organs is considered appropriate when there is a high probability that the body will return to normal or close to normal activity. At the same time, in a situation when it is hardly possible to expect restoration of the vital functions of the body, Orthodox ethics do not support the practice of euthanasia, rejecting the very possibility of deliberate interrupting the life of a dying patient. It considers this action as a special case of murder if it occurs without the patient's knowledge or suicide if it occurs with patient's knowledge. An important point in the denial of euthanasia in Orthodox bioethical discourse lies in the impossibility of distinguishing between "tolerable" and "unbearable" suffering, especially taking into account that Orthodoxy attached particular importance to the possibility of spiritual growth through suffering (Рим. 11.8: 17-39) (Kharakas, 1998: 322).

The Orthodox Church defends the inadmissibility of not natural actions, carried out "against human nature", towards the "living". The orthodox bioethical discourse considers artificial insemination one of such actions. For the Orthodox Church, human sexuality and natural reproductive functions are divine dimensions of life that are embodied in the sacrament of marriage and the upbringing of children. Therefore, the practice of fertilizing an egg-cell invitro with sperm of an anonymous donor, surrogate motherhood, the use of contraceptives are sharply denied in Orthodox bioethical discourse since they are unnatural, because they are caused by the desire of artificial control of human sexuality and reproduction. Artificial insemination of an unmarried woman is condemned by Orthodoxy, primarily on the basis of the interests of the unborn child. In this case, the child is born outside the sacred marriage union and in advance loses the opportunity to be raised in a complete family. Ethical protest in the Orthodox discourse is caused by the very idea of "anonymous paternity", when father is not burdened with any responsibility. Similarly, artificial insemination of a married woman is considered unacceptable, since it "provides for the actual destruction of marital fidelity" (Balashov, 1998: 149). The Orthodox discourse interprets the unnatural form of fertilization as a step towards the dehumanization of human life near the very origins of it. The basis of the moral blame of such clinical actions is the idea of protecting the integrity and 
uniqueness of relationships in marriage, as well as understanding the human embryo as a carrier of human dignity. The Orthodox Church sees impossible the neglect of a deep spiritual and emotional connection in the family and marriage, as well as between the mother and the unborn child. The clinical practice of destroying or experimentally use excessive embryos is recognized as a form of infanticide as an intended abortion.

The moral problem of organ transplantation still remains unsolved within the framework of Christian bioethical discourse. This phenomenon gives rise to issues of the relation of the recipient and the donor. At the same time, Christian bioethics warns against ignoring or thoughtless attitude to solving this problem.

\section{Conclusions}

The author's analysis of the specificities of the scientific discourse relative to the definition of the concept of "living" allowed establishing the categorical framework of the studied problems. It also made possible to find out that the transition from the biological paradigm of existence of the living to the bioethical paradigm, which includes the moral aspects of the existence of the living, is the basis of modern approaches.

The modern anthropological crisis is, above all, the subject of axiological reflection. The value perception of the changes taking place is specified as a danger in the existence of the "living". Since life occupies a dominant place in the hierarchy of human values, the attitude to it runs through the whole existence of a person, while actualizing its moral meaning and content of the term. Bioethics defines the boundaries of the possible human impact on the ways and forms of the existence of the living through moral norms. Modern religious and ethical discourse forms a system of categories and concepts that describe applied ethical conceptual constructs in order to form a person's moral attitude to all living. The proposed author's approach allowed establishing the essence of modern bioethical discourse in the study of "living".

\section{REFERENCES}

Rikkert, G. (1998). Filosofia zhizni. Kiyv: Nika-Tsentr: Vist-S (In Russian).

Averintsev, S. (1989). Filosofskiy entsiklopedicheskiy slovar. Moscow, P. 192 (In Russian).

Plato (1971). Timey (translat. from ancient Greek). Moscow (In Russian).

Plato (1999). Zakony (translat. from ancient Greek). Moscow (In Russian).

Aristotle (2000). Politics (translat. from ancient Greek). Kyiv (In Ukrainian)

Plotinus (1995). Eneady (translat. from ancient Greek). Kyiv, P. 348-352 (In Russian).

Dyachenko, G. (1993). Polnyy Tserkovno-slavyanskiy slovar. Moscow (In Russian).

Mc Donald, H. D. (2003). The View of Man. Theological Dictionary (translat. from English). Moscow (In Russian).

Horban, O. and Martych, R. (2017). Basic approaches to the definition of the essence of the concept of "living". Studia Warminskie, nr 54, p. 93-103. (In Russian).

Horban, O. and Martych, R. (2018). Axiological determinants of the doctrine of "living" in modern bioethic discourse. Studia Warminskie. nr 55, p. 93-106. (In Russian).

Siluyanova, I. V. (2001). Bioetika v Rossii: tsennosti i zakony. Moscow: Grant (In Russian).

Collange, J.-F. (1992). Bioetika i protestantizm in Medicine and Human Rights. Moscow: Progress-Inter, p. 41-44. (In Russian).
Stott, J. (2004). Novyye problemy khristian (translat. from English). Cherkassy: SMIRNA (In Russian).

Boyko, I. Ye. (2011). Identychnist i status lyudskoho embriona u suchasnykh bioetychnykh dyskusiyakh. Naukovi zapysky Natsionalnoho universytetu "Ostrozka akademiya". Seriya: Filosofiya, Issue 8. Pp. 217-229 (In Ukrainian).

Donum Vitae: Instruction on Respect for Human Life in Its Origin and on the Dignity of Procreation Replies to certain questions of the day. Retrieved from http://www.vatican.va/ roman curia/congregations/cfaith/documents/rc con cfaith_doc_19870222_respect-for-human-life_en.html (23.04.2019) (In English)

Horban, O. and Martych, R. (2017). Fenomen "zhyvoho" v kontekste sovremennoho pravoslavnoho dyskursa. Naukovi pratsi Chornomorskoho natsionalnoho universytetu im. Petra Mohyly. Seriya Filosofiya. Vol. 300, Issue 288, pp. 55-59 (In Russian).

Saint Basil the Great (2008). Pravyla svyatoho Vasyliya Velykoho v Knyha pravyl svyatykh apostoliv vselenskykh i pomisnykh soboriv, i svyatykh ottsiv. Ukrayinska pravoslavna tserkva Kyyivskoho patriarkhatu, Kyiv. (In Ukrainian).

Melety (Metropolitan of Nikopol) (1992). Aborty (Otnosheniye k nim Pravoslavnoy Tserkvi). Kyiv: Izdatelstvo UFIMB (In Russian). Kharakas, S. (1998). Pravoslaviye i bioetika. Bioetika: printsipy, pravila, problemy. Moscow: Editorial URSS (In Russian).

Balashov, N. (1998). Iskusstvennoye oplodotvoreniye: chto dumayut pravoslavnyye? Bioetika: printsipy, pravila, problemy, Moscow: Editorial URSS (In Russian).

\section{LIST OF REFERENCE LINKS}

Риккерт Г. Философия жизни. Киев: Ника-Центр: Вист-С, 1998.

Аверинцев С. Философский энциклопедический словарь. Москва, 1989. 192 с.

Платон. Тимей. Москва, 1971.

Платон. Законы. Москва, 1999.

Арістотель. Політика. Київ, 2000.

Плотин. Энеады. Киев, 1995. С. 348-352.

Дьяченко Г. Полный Церковно-славянский словар. Москва, 1993.

Mc Donald H. D. The View of Man. Теологический словарь. Москва, 2003.

Horban O., Martych R. Basic approaches to the definition of the essence of the concept of "living". Studia Warminskie. 2017, nr 54, p. 93-103.

Horban O., Martych R. Axiological determinants of the doctrine of "living" in modern bioethic discourse. Studia Warminskie. 2018. № 55. P. 93-106.

Силуянова И. В. Биоэтика в России: ценности и законы. Москва: Грант, 2001.

Колланж Ж.-Ф. Биоэтика и протестантизм в Медицина и права человека. Москва: ИГ "Прогресс", "Прогресс-Интер", 1992. С. 41-44.

Стотт Дж. Новые проблемы христиан. Черкассы: СМИРHA, 2004

Бойко І. Є. Ідентичність і статус людського ембріона у сучасних біоетичних дискусіях. Наукові записки Національного університету "Острозька академія". Серія: Філософія, 2011. Випуск 8. С. 217-229.

Donum Vitae: Instruction on Respect for Human Life in Its Origin and on the Dignity of Procreation Replies to certain questions of the day. URL: http://www.vatican.va/roman curia/congregations/cfaith/documents/rc_con_cfaith_doc_19870222_respectfor-human-life_en.html (Дата звернення: 23.04.2019).

Горбань О., Мартич Р. Феномен "живого" в контексте современного православного дискурса. Наукові праці Чорно- 
морського національного університету ім. Петра Могили. Серія Філософрія. 2017, Том 300, Випуск 288, С. 55-59.

Василій Великий. Правила святого Василія Великого в

"Книга правил святих апостолів вселенських і помісних соборів, і святих отців". Київ: Українська православна церква Київського патріархату, 2008.

Мелетий (Митрополит Никопольский). Аборты (Отноше- ние к ним Православной Церкви). Киев: Издательство УФИМБ, 1992.

Харакас С. Православне и биоэтика. Биоэтика: принципы, правила, проблемы. Москва: Эдиториал УРСС, 1998.

Балашов Н. Искусственное оплодотворение: что думают православные? Биоэтика: принципы, правила, проблемы. Москва: Эдиториал УРСС, 1998.

Мартич Руслана,

Київський університет імені Бориса Грінченка (м. Київ, Україна)

e-mail:r.martych@kubg.edu.ua,DOI0000-0002-7755-4496

\section{ЕВОЛЮЦІЯ УЯВЛЕНЬ ПРО "ЖИВЕ" В РЕЛІГІЙНО-ФІЛОСОФСЬКОМУ ДИСКУРСІ}

Сучасний науковий дискурс, який має в своїй основі постнекласичну наукову картину світу і ґрунтується на перманентно-транзитивних флуктуаціях епохи постмодерну, все ж включає в себе такі одвічні питання, як проблема людини, ї̈ життя і здоров'я, основних факторів буття світу і людського буття в світі. Життя - це єдиний біологічно можливий спосіб буття людини в світі. Цінність його полягає не тільки в особливостях існуючих біологічних форм і різноманітних проявів, які є, проте, в своїй сукупності унікальним феноменом буття, але і в можливості саморефлексії, усвідомленого переживання самого явища і здатності до формування на цій основі символічних картин буттєвого світу. Метою даної роботи є дослідження трансформації наукового дискурсу щодо поняття "живого" в рамках становлення і розвитку релігійно-етичних вчень. Для реалізації цієї мети автором аналізується категоріальний каркас поняття "живого". Аналізуючи класичні філософські та сучасні наукові підходи до визначення поняття "живого", автором виділяються два основні підходи до визначення життя - субстратний і функціональний. Основна увага в статті зосереджена на аналізі релігійного та біоетичного дискурсів у вченні про "живе". Біоетичний дискурс виходить з необхідності виявлення моральних норм та імперативів, здатних відповідати на питання про межі існування "живого" і визначати моральні можливості впливу (розширення або звуження) на ці кордони. Однією з фундаментальних проблем біоетики є проблема життя як цінності. У сучасному біоетичному дискурсі сформувалися дві основні точки зору 3 цього приводу. Першу можна назвати етикою сакральності життя або життя як найвищої цінності (sanctity of life), другу - етикою якісного життя (quality of life). Сакральність життя передбачає ставлення до феномену "живого" як до об'єкта виняткової ваги, найважливішої цінності і на цій підставі вимагає побожного до нього відношення. Найбільш яскраво і повно такий підхід представлений сучасним релігійним дискурсом. Релігійний зміст біоетичного дискурсу про "живе" проявляється по-перше, в утвердженні християнським персоналізмом об'єктивного онтологічного статусу людської особистості; по-друге, у вченнях християнських теологів, які стверджують красу і праведність життя, створеного Богом, де природа і людина в ній розуміються як щось сакральне, а тому дії, викликані проти них - грішні і неприпустимі; по-третє, основа людського життя корениться в духовному світі самої людини, співвіднесеного з божественною трансценденцією. Зроблено висновок про те, що сучасний релігійно-етичний дискурс формує систему категорій і концептів, що описують прикладні етичні понятійні конструкти з метою формування морального ставлення людини до всього живого. Запропонований авторський підхід дозволив зафіксувати сутність сучасного біоетичного дискурсу у вченні про "живе".

Ключові слова: буття; людина; життя; живе; концепт; дискурс; релігія; етика; біоетика; цінність.

(c) Martych Ruslana

Надійшла до редакції: 22.05.2019

Прийнята до друку: 10.06.2019 